\title{
Contribution of Soil and Water Conservation Techniques to Soil Carbon Sequestration in a Forest Ecosystem in West Africa (Burkina Faso)
}

\author{
Jérôme T. Yameogo ${ }^{1}$, Kalifa Coulibaly², \\ Tatiana M. C. Compaore ${ }^{3}$, Antoine N. Some ${ }^{1}$, Hassan B. Nacro ${ }^{2}$
}

\begin{abstract}
${ }^{1}$ Laboratoire des Systèmes Naturels, des Agrosystèmes et de 1'Ingénierie de l'environnement (SyNAIE), Institut du Développement Rural (IDR), Université Nazi Boni (UNB), BP 1091, Bobo-Dioulasso, Burkina Faso.

${ }^{2}$ Laboratoire D'étude et de Recherche sur la Fertilité du sol (LERF), Institut du Développement Rural (IDR), Université Nazi Boni, BP 1091, Bobo-Dioulasso, Burkina Faso

${ }^{3}$ Université Abdou Moumouni, faculté d'agronomie BP 10960 niamey-niger
\end{abstract}

\begin{abstract}
Kuinima forest ecosystem, a classified forest, located in western Burkina Faso, is undergoing accelerated degradation due to climatic hazards and anthropogenic factors such as excessive cutting of trees, bush fires, etc. The main objective of this study is to assess the contribution of three water and soil conservation techniques (Zaï forest, stone rows, Zaï forest+ stone rows) to soil carbon sequestration and their impact on some soil physicochemical parameters. Thus, soil samples were taken, and the physicochemical parameters of the soil were analyzed in the laboratory. The organic carbon stock was calculated based on the results of the carbon content analysis. The results revealed that the treatments had higher clay and silt contents than the control. The treatments also had a significant impact on soil organic carbon content, total nitrogen, available potassium and cation exchange capacity over the 0 $20 \mathrm{~cm}$ depth. Compared to the control, the Zaï forest, Zaï forest+stone rows and stone rows treatments led to respective increase in the carbon stock of $166 \%, 77 \%$ and $21 \%$. In conclusion, this study has shown that Zaï forest and stone rows can contribute significantly to soil carbon sequestration to fight against climate change.
\end{abstract}

Keywords: Zaï Forest, Carbon Stock, Climate Change, Stone Rows, Burkina Faso

\begin{abstract}
Introduction
Climate change is a current phenomenon that affects all the countries in the world. It causes rising temperatures, rising sea levels and accentuates soil degradation, droughts, famines, seasonal disruption, diseases, seismic activities, etc. As a result, it is a problemand a debate of great concern in the scientific community for the past decades (Koala, 2016).
\end{abstract}

Climate change is due to the emission of huge amounts of greenhouse gases for many years, especially from the industrial revolution (Ouoba et al., 2013). The most affected continents are Africa and Asia (Ouattara et al. 2008; Hassan, 2010). These gases come largely from human activities such as industrial pollution, land-use change, agricultural intensification, deforestation, spraying of synthetic or inorganic agro-chemicals, increased road traffic, etc. (Robert and Saugier, 2003).

Dryland ecosystems cover about one-third of the Earth's surface and play a crucial role in the global carbon cycle because the soil in these systems store $15.5 \%$ of the world's soil organic carbon (SOC) (Jobbágy and Jackson, 2000). However, most of these regions have been degraded and turned into desert by the combined effects of climate change, deforestation, excessive grazing and improper use of water (Li et al., 2016).

Forest ecosystems store more than $80 \%$ of all terrestrial aboveground $\mathrm{C}$ and more than $70 \%$ of all soil organic C (Jobbágy and Jackson, 2000; Six et al., 2002). An increase in soil respiration would increase the $\mathrm{CO}_{2}$ emissions from forest ecosystems. In order to mitigate climate change, more $\mathrm{C}$ should be sequestered in forest ecosystems and strategies for an adapted forest management are sought (Jandl et al., 2007).

The terrestrial ecosystems mitigate the impact of these emissions while capturing, sequestering and trapping more thanone-third of the carbon. The main mechanisms used to achieve these effects are 
photosynthesisand, the respiration of plants (marine or terrestrial) and soil microorganisms, considered as reservoirs of carbon orcarbon sink. Fromthe decade 2004-2013, the world ocean absorbed 2.6 billionof tonnes of carbon per year, which represents nearly $30 \%$ of the human emission during this period (Bopp et al., 2015).

The soil is the biggest reservoir of carbon on the planet, with 615 billions of tonnes in the first 20 centimeters and 2344 billions of tonnes down to a depth of 3 meters (IAD, 2013). According to the INRA (2015), to increase every year the stock of carbon in soils by 4 for 1000 in the first 40 centimeters of soil would permit, in theory, to stop the present increase of the quantity of $\mathrm{CO}_{2}$ in the atmosphere, in order to put an end to deforestation. Thus, the growth of carbon storage as organic matter of soils could play an important role in the struggle against the increase of greenhouse gases effects in the atmosphere and therefore in the prevention ofclimatic change (Arrouays et al., 2003).

In Africa, in addition to climate change, the phenomenon of the rapid increase in demography also exists. These two combined situations generated a serious or an irreversible deterioration of the soil. According to Gomgnimbou et al. (2010), more than $65 \%$ of the African agricultural soils are damaged due to human activities. The productions and the incomes coming from traditional practices of breeding and agriculture as means of subsistence, become more and more precarious (Koala, 2016).

To adapt themselves to it, populations have resorted to a multitude of strategies among which the soils and waters conservation techniques which are the subject of our study.

The general objective of this study is to assess the potential of carbon sequestration to augment the existing mechanisms against desertification and the rehabilitation of damaged soils and their impact on some physicochemical parameters of soil.

\section{Materials and methods}

\section{1 Study area}

The study was carried out in the classified Forest of Kuinima. It is located in west Burkina Faso between $11^{\circ} 03^{\prime}-11^{\circ} 7^{\prime} \mathrm{N}$ and $04^{\circ} 19^{\prime}-04^{\circ} 36^{\prime} \mathrm{W}$ (Figure 1). It had a surface of 4000 ha in 1935; presently it only covers a surface of 2150 ha. The other part has been relegated in May 1947. The area has a south-sudanian climate with two seasons, a rainy season from June to September and a dry season from October to May (Fontes and Guinko, 1995). The average annual rainfall is $1000 \mathrm{~mm}$ and the average annual temperature is $30{ }^{\circ} \mathrm{C}$. The soils are mainly tropical ferruginous andthe slope ranging from 3 to $4 \%$.
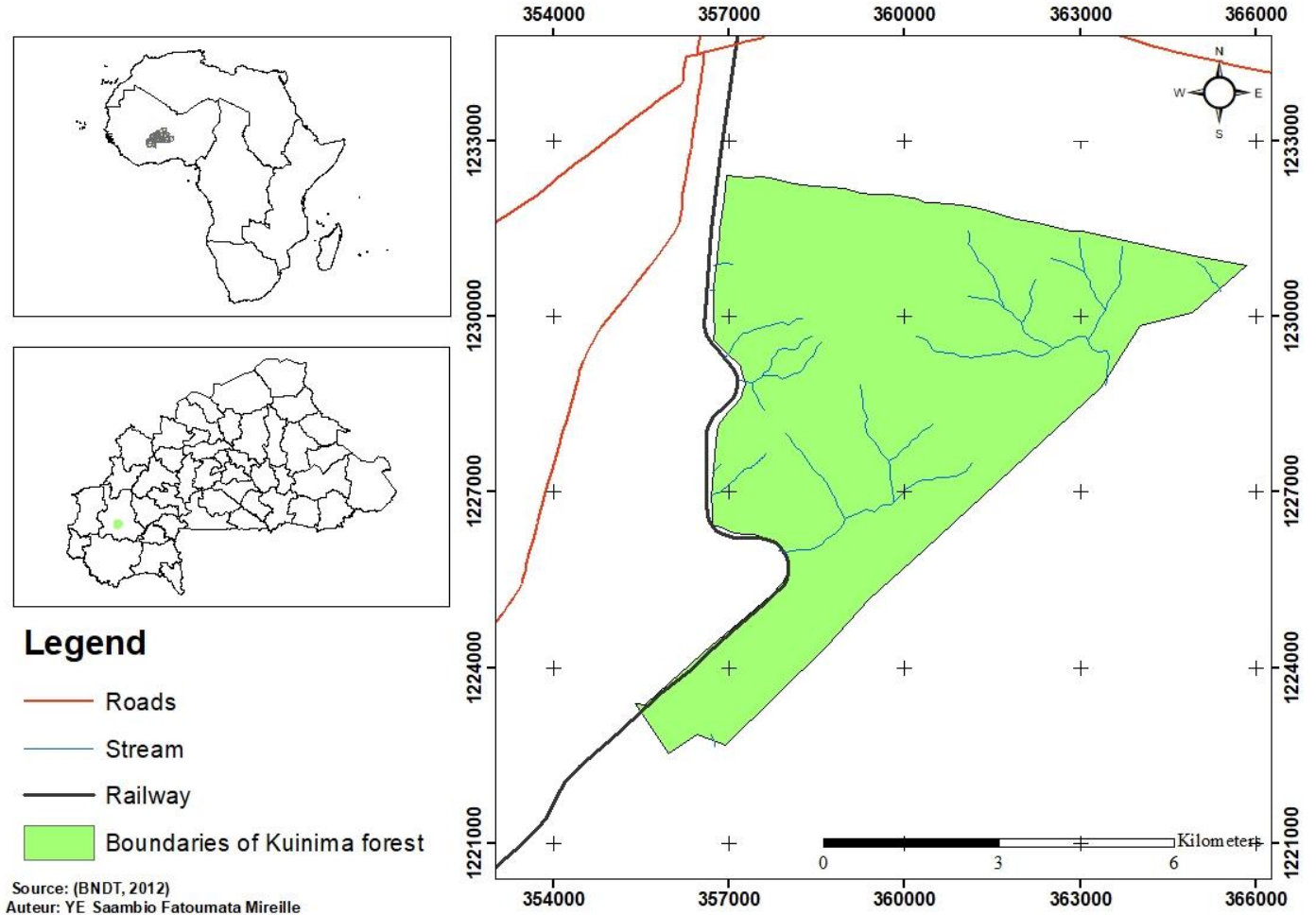

Figure 1 : Location of Kuinima classified forest 


\section{I.2 Experimental setup}

The experimental setup was a Fischer completely randomized block design with three treatments and a control with three replicates. The three treatments were stone-rows (SR), Zaï forest (ZF) and zaï forest combined with stone-rows ZF-SR). The stone-rows are anti-erosive pieces of work made of carefully arrangement of stones onlevel curves. The Zaï forest is a seed hole of $15 \mathrm{~cm}$ of depth and a diameter of about $20 \mathrm{~cm}$ (Yaméogo et al., 2013).

\section{I.3 Soil sampling}

Two types of soil samples were collected at each plot level: composite soil samples and cumulative mass soil samples. Composite soil samples were taken from three points in each plot. The first point is situated in the center of the plot and the two othersat $12.5 \mathrm{~m}$ of the center with respect to the plot length. Samples were taken at $0-20 \mathrm{~cm}$ depth for the characterization of the initial state in 2007 and at 0 $20 \mathrm{~cm}$ and $20-40 \mathrm{~cm}$ depths for the follow-up in 2016. In each plot, the samples of the same depth were mixed to constitute a composite sample, and $700 \mathrm{~g}$ of soils were taken for laboratory analyses.

Cumulative mass soil samples were collected in the center of each plot with a soil auger and a metallic plate of sampling used as an auger guide, to prevent collapse of the hole near the surface, and to aid full recovery of the soil sample (Figure 2). For each depth, the whole soil was collected to estimate bulk density of the soil (Aynekulu et al., 2011)

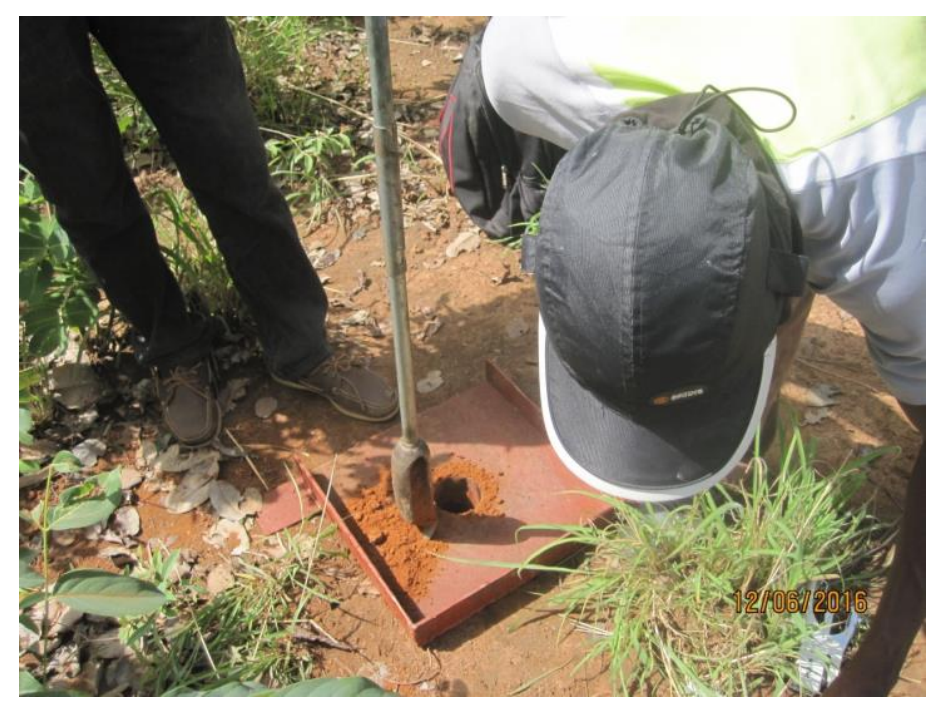

Figure 2 : Photo of cumulative mass soil sampling (Compaoré M. C. Tatiana 12/06/2016).

\section{I.4 Soil analysis}

Soil texture analyses were achieved using the pipette method (Loveland and Whalley, 1991). The pH was measured with the $\mathrm{pH}$-water method using a 1:2.5 soil/water suspension following the procedure described by Sahilemedhin and Taye (2000). Soil organic carbon (SOC) content was measured following the wet oxidation method (Walkley and Black, 1934). Total exchangeable phosphorus (ExcP) by the Bray I method (van Reeuwijk, 2002), and available potassium (Avail-K) by atomic absorption spectrometry after extraction of ammonium acetateextractable cations ((BUNASOLS, 1987). Exchangeable base cations $\left(\mathrm{Ca}^{2+}, \mathrm{Mg}^{2+}, \mathrm{K}^{+}\right.$and $\left.\mathrm{Na}^{+}\right)$ contents and soil cation exchange capacity (CEC) were determined using inductively coupled plasma spectrometry (BUNASOLS, 1987) and total nitrogen (N) by the Kjeldahl method (Bremner, 1965).

\section{I.5Calculation of soil organic carbon stocks}

The soil organic carbon stock assessment was made according to the procedure described by Aynekulu et al. (2011). The cumulative mass soil of each plot was air-dried and the entire air-dried soil sample was weighed to $0.1 \mathrm{~g}$ and recorded (EAS=entire air-dried soil). To determine gravimetric moisture content on the sample, a labeled sample tin was weighed for taking oven-dry moisture content and its weight recorded (TE=tin empty). An approximately $50 \mathrm{~g}$ representative subsample of the original sample was taken and placed into the weighed sample tin and tin + air-dried soil weight was recorded (TAS $=$ tin+airdriedsoil). Tin + air-dried soil was placed into an oven at $105{ }^{\circ} \mathrm{C}$ until a constant weight was obtained ( 48 hrs.). Once the soil was dry, tin + oven-dried soil were weighed and the weight was recorded (TAS1). The gravimetric moisture (GM) content was calculated with the following equation: $G M=\left(\frac{(T A S-T E)-(T A S 1-T E)}{(T A S 1-T E)}\right) \times 100$

To determine the percentage of the coarse fraction, the rest of the air-dried soil and after having been taken from the $50 \mathrm{~g}$ of the parboiling, is sieved with a 
sieve of $2 \mathrm{~mm}$ to obtain the mass of the coarse fragments $(\mathrm{CF})$.

The percentage of the coarse fraction was obtained by the following formula:

$\operatorname{Frag}(\%)=\frac{C F}{E A S-50} \times 100$

$\mathrm{CF}=$ mass of coarse fragments; $\mathrm{EAS}=$ Total mass of air-dried soil.

To calculate the organic carbon stock in an equivalent soil mass, three types of variables were measured: soil organic carbon concentration, soil bulk density, and soil depth.

Soil bulk density was calculated from ovendried soil weight of a given soil volume (Aynekulu et al., 2011).

$\rho=\frac{M}{V}$

$\rho=$ bulk density $\left(\mathrm{g} \mathrm{cm}^{-3}\right)$

$\mathrm{M}=$ oven-dryweight of soil $(\mathrm{g})$;

$\mathrm{V}=$ volume of soil $\left(\mathrm{cm}^{-3}\right)=\pi \mathrm{r}^{2} \mathrm{p}$;

$\mathrm{r}=$ auger radius and $\mathrm{p}=$ sampling depth in $\mathrm{cm}$.

The organic carbon stock was obtained by (Aynekulu et al., 2011):

SOC $=\frac{C}{100} \times \rho \times D \times(1-$ frag $) \times 100$

Where :

$\mathrm{SOC}=$ soil organic carbon stock $\left(\mathrm{t} \mathrm{C} \mathrm{ha}^{-1}\right)$;

$\mathrm{C}=$ soil organic carbon concentration of fine soils(fraction $<2 \mathrm{~mm}$ ) determined in the laboratory $\left(\%, \mathrm{~g} \mathrm{~kg}^{-1}\right)$;

$\rho=$ soil bulk density $\left(\mathrm{g} \mathrm{cm}^{-3}\right)$;
$\mathrm{D}=$ depth of the sampled soil layer $(\mathrm{cm})$;

frag $=\%$ mass fraction of the coarse fragments $/ 100$; 100 was used to convert the units to $\mathrm{C} \mathrm{ha}^{-1}$.

\section{I.6 Statistical analysis}

After the normality verification with Shapiro-Wilk test, the data were processed with ANOVAusing the XLSTAT 7.5 software. The test of Newman-Keuls was used to compare averages at the $5 \%$ level of significance.

\section{Results}

\section{II.1. Physical parameters}

The initial physical characterization of the soil did not show a significant difference $(p>0.05)$ between treatments for $0-20 \mathrm{~cm}$ depth (Table 1).

After ten years of application, ZF-SR treatments; ZF and SR had significantly higher clay and silt contents (p <0.05) than $\mathrm{C}$ in the $0-20 \mathrm{~cm}$ depth (Table 1). Indeed, ZF-SR recorded the highest content of clay (248.8 $\left.\mathrm{gkg}^{-1}\right)$ and silt $\left(274.8 \mathrm{gkg}^{-1}\right)$, and the lowest levels of these elements were observed in $\mathrm{C}$. However, the higher sand content was observed in $\mathrm{C}$ $\left(652.5 \mathrm{gkg}^{-1}\right)$ and the lowest in ZF-SR $\left(476.5 \mathrm{gkg}^{-1}\right)$.

In the 20-40 $\mathrm{cm}$ depth, the analysis of variance did not show any significant differences $(\mathrm{P}>0.05)$ between the different treatments in 2016 .

Table 1: Soil texture of different treatments

\begin{tabular}{|c|c|c|c|c|c|c|c|}
\hline \multirow[t]{2}{*}{ Depth } & \multirow[b]{2}{*}{ Treatment } & \multicolumn{2}{|l|}{ Clay $\left(\mathrm{gkg}^{-1}\right)$} & \multicolumn{2}{|l|}{$\operatorname{Silt}\left(\mathrm{gkg}^{-1}\right)$} & \multicolumn{2}{|l|}{ Sand $\left(\mathrm{gkg}^{-1}\right)$} \\
\hline & & 2007 & 2016 & 2007 & 2016 & 2007 & 2016 \\
\hline \multirow{6}{*}{$0-20 \mathrm{~cm}$} & ZF-SR & $202.2 \pm 12.4^{\mathrm{a}}$ & $248.8 \pm 23.3^{\mathrm{a}}$ & $223.3 \pm 43.1^{\mathrm{a}}$ & $274.8 \pm 19.6^{\mathrm{a}}$ & $574.57 \pm 54.2^{\mathrm{a}}$ & $476.5 \pm 30.8^{\mathrm{c}}$ \\
\hline & $\mathrm{ZF}$ & $194.5 \pm 73.6^{a}$ & $222.2 \pm 29.9^{\mathrm{a}}$ & $215.5 \pm 09.6^{a}$ & $235.3 \pm 19.6^{\mathrm{b}}$ & $590.00 \pm 26.5^{\mathrm{a}}$ & $542.5 \pm 49.3^{\mathrm{b}}$ \\
\hline & SR & $198.6 \pm 32.7^{\mathrm{a}}$ & $216.4 \pm 09.4^{\mathrm{a}}$ & $215.5 \pm 42.8^{\mathrm{a}}$ & $219.3 \pm 05.8^{b}$ & $585.91 \pm 04.2^{\mathrm{a}}$ & $564.4 \pm 05.8^{b}$ \\
\hline & $\mathrm{C}$ & $210.6 \pm 81.3^{a}$ & $172.5 \pm 05.6^{\mathrm{b}}$ & $199.6 \pm 19 a$ & $175.0 \pm 10.2^{\mathrm{c}}$ & $589.82 \pm 15.5^{\mathrm{a}}$ & $652.5 \pm 15.5^{\mathrm{a}}$ \\
\hline & Probability & 0.12 & 0.01 & 0.07 & $<0.01$ & 0.49 & $<0.01$ \\
\hline & Significance & NS & $\mathbf{S}$ & NS & VHS & NS & HS \\
\hline \multirow{6}{*}{$20-40 \mathrm{~cm}$} & ZF-SR & - & $281.0 \pm 22.6^{\mathrm{a}}$ & - & $248.4 \pm 49.3^{\mathrm{a}}$ & - & $470.6 \pm 33.9^{\mathrm{a}}$ \\
\hline & $\mathrm{ZF}$ & - & $326.8 \pm 40.8^{\mathrm{a}}$ & - & $241.8 \pm 11.3^{\mathrm{a}}$ & - & $431.4 \pm 33.9^{\mathrm{a}}$ \\
\hline & SR & - & $284.9 \pm 40.7^{\mathrm{a}}$ & - & $215.9 \pm 28.0^{\mathrm{a}}$ & - & $499.2 \pm 12.7^{\mathrm{a}}$ \\
\hline & $\mathrm{C}$ & - & $261.6 \pm 05.9^{\mathrm{a}}$ & - & $238.4 \pm 06.4^{\mathrm{a}}$ & - & $500.1 \pm 0.8^{\mathrm{a}}$ \\
\hline & Probability & - & 0.14 & - & 0.68 & - & 0.05 \\
\hline & Significance & - & NS & - & NS & - & NS \\
\hline
\end{tabular}

ZF :Zaï forest; SR : Stone rows, ZF-SR : Zaïforest+stone rows; $\mathrm{C}=$ control

NS = No significant; $S$ : Significant; HS : High significant ; VHS : Very high Significant

The treatments with the same letter in the same column are not statistically different at $\mathrm{p}=0.05$ with Student-

Newman-Keuls test for this parameter

\section{II.2. Chemical parameters}

Table 2 and 3 present the results of the chemical soil analysis at $0-20 \mathrm{~cm}$ and $20-40 \mathrm{~cm}$ depths. The initial soil chemical parameters(Table 2) did not show significant differences between treatments $(\mathrm{p}>0.05)$. After ten years, highly significant differences were observed between treatments for the soil chemical parameters SOC and $\mathrm{N}(\mathrm{p}<0.01)$ in the depth $0-20 \mathrm{~cm}$ but no significant differences were noticed for the same parameters in the $20-40 \mathrm{~cm}$ depth (Table 3 ). For these two respective parameters, the higher values were observed in ZF-SR $\left(10 \mathrm{gkg}^{-1}\right.$ and0.8 $\left.\mathrm{gkg}^{-1}\right)$ and ZF (11.3 $\mathrm{gkg}^{-1}$ and $\left.0.8 \mathrm{gkg}^{-1}\right)$. Their lower values were found in $\mathrm{C}\left(5.3 \mathrm{gkg}^{-1}\right.$ and $\left.0.4 \mathrm{gkg}^{-1}\right)$. The content of avail-K was significantly higher $(\mathrm{p}<0.01)$ in $\mathrm{ZF}$ SR for the two depths and only in the $0-20 \mathrm{~cm}$ depth 
for ZF. Furthermore, the CEC was significantly different $(p<0.05)$ between the treatments only in the $20-40 \mathrm{~cm}$ depth. Its higher values were found in $\mathrm{ZF}$ $(7.84 \mathrm{cmol} / \mathrm{kg})$ and ZF-SR $(6.89 \mathrm{cmol} / \mathrm{kg})$. Its lower value was found in $\mathrm{C}(5.43 \mathrm{cmol} / \mathrm{kg})$. The sum of exchangeable base cation (SBE) was significantly higher $(\mathrm{p}<0.01)$ in $0-20 \mathrm{~cm}$ depth for $\mathrm{ZF}(2.77$ $\mathrm{cmol} / \mathrm{kg})$ and ZF-SR $(2.11 \mathrm{cmol} / \mathrm{kg})$. There were no significant differences between the treatments for pHwater, Exc-P and V ( $>0.05)$.

Table 2: Initial soil chemical characteristics in the experimental plots (3 replicates)

\begin{tabular}{lllllllll}
\hline Treatments & $\mathrm{pH}$ water & $\begin{array}{l}\text { SOC (gkg- } \\
1)\end{array}$ & $\mathrm{N}\left(\mathrm{gkg}^{-1}\right)$ & $\begin{array}{l}\text { Exc-P (mg } \\
\left.\mathrm{kg}^{-1}\right)\end{array}$ & $\begin{array}{l}\text { Avail-K } \\
\left.(\mathrm{mg} \mathrm{kg})^{-1}\right)\end{array}$ & $\begin{array}{l}\text { CEC } \\
(\mathrm{cmol} \\
1)\end{array}$ & $\begin{array}{l}\text { kg- } \\
\left.\mathrm{kg}^{-1}\right)\end{array}$ & \\
\hline ZF-SR & $4.79 \pm 0.27$ & $7.53 \pm 0.65$ & $0.65 \pm 0.10$ & $1.89 \pm 0.87$ & $17.8 \pm 1.06$ & $3.22 \pm 0.31$ & $1.69 \pm 0.41$ & $51.84 \pm 0.20$ \\
ZF & $4.29 \pm 0.05$ & $6.08 \pm 0.09$ & $0.71 \pm 0.09$ & $1.69 \pm 0.07$ & $13.7 \pm 0.78$ & $3.16 \pm 0.43$ & $1.57 \pm 0.34$ & $43.87 \pm 4.06$ \\
SR & $4.82 \pm 0.13$ & $6.43 \pm 1.07$ & $0.55 \pm 0.01$ & $1.73 \pm 0.12$ & $16.63 \pm 0.65$ & $3.28 \pm 0.13$ & $1.96 \pm 0.62$ & $49.43 \pm 1.24$ \\
C & $4.31 \pm 0.23$ & $6.12 \pm 0.51$ & $0.57 \pm 0.34$ & $1.84 \pm 0.21$ & $14.33 \pm 1.23$ & $4.17 \pm 0.50$ & $2.16 \pm 0.21$ & $48.15 \pm 3.24$ \\
Probability & 0.14 & 0.37 & 0.11 & 0.91 & 0.35 & 0.22 & 0.19 & 0.13 \\
Significance & NS & NS & NS & NS & NS & NS & NS & NS \\
\hline
\end{tabular}

$\mathrm{ZF}$ :Zaï forest; SR : Stone rows, ZF-SR : Zaïforest+stone rows; $\mathrm{C}=$ control

$\mathrm{SOC}=$ Soil organic carbon, $\mathrm{N}=$ Total nitrogen, Exc-P= Exchangeable phosphorus, Avail-K = Available potassium, $\mathrm{CEC}=$ Cation exchange capacity, $\mathrm{SBE}=$ sum of exchangeable bases, NS = No significant, $\mathrm{V}=$ Rate of saturation;

Table3: Soil chemical parameters of treatments on 0-20 and 20-40 cm depths (3 replicates)

\begin{tabular}{|c|c|c|c|c|c|c|c|c|c|}
\hline depths & Treatments & pHwater & $\begin{array}{l}\text { SOC } \\
\left(\mathrm{gkg}^{-1}\right)\end{array}$ & $\begin{array}{l}\mathrm{N} \\
\left(\mathrm{gkg}^{-1}\right)\end{array}$ & $\begin{array}{l}\text { Exc-P } \\
\left(\mathrm{mgkg}^{-1} \mathrm{sol}\right)\end{array}$ & $\begin{array}{l}\text { Avail-K } \\
\left(\mathrm{mgkg}^{-1} \text { sol) }\right.\end{array}$ & $\begin{array}{l}\mathrm{CEC} \\
\left(\mathrm{cmolkg}^{-1}\right)\end{array}$ & $\begin{array}{l}\mathrm{SBE} \\
\left(\mathrm{cmolkg}^{-1}\right)\end{array}$ & $\mathrm{V}(\%)$ \\
\hline \multirow{6}{*}{$0-20 \mathrm{~cm}$} & ZF-SR & $5.19 \pm 0.17^{\mathrm{a}}$ & $10.0 \pm 1.02^{\mathrm{a}}$ & $0.8 \pm 0.04^{\mathrm{a}}$ & $2.68 \pm 0.20^{\mathrm{a}}$ & $63.13 \pm 11.02^{\mathrm{a}}$ & $6.72 \pm 0.81^{\mathrm{a}}$ & $2.11 \pm 0.25^{\mathrm{a}}$ & $31.36 \pm 0.34^{2}$ \\
\hline & ZF & $5.14 \pm 0.04^{\mathrm{a}}$ & $11.3 \pm 1.00^{\mathrm{a}}$ & $0.8 \pm 0.06^{\mathrm{a}}$ & $2.76 \pm 0.17^{\mathrm{a}}$ & $60.45 \pm 4.63^{\mathrm{a}}$ & $7.53 \pm 1.36^{\mathrm{a}}$ & $2.77 \pm 0.55^{\mathrm{a}}$ & $36.95 \pm 6.23=$ \\
\hline & SR & $5.20 \pm 0.15^{\mathrm{a}}$ & $08.7 \pm 0.16^{b}$ & $0.7 \pm 0.02^{\mathrm{a}}$ & $3.29 \pm 1.95^{\mathrm{a}}$ & $48.43 \pm 6.12^{\mathrm{b}}$ & $5.89 \pm 1.21^{\mathrm{a}}$ & $1.74 \pm 0.40^{\mathrm{b}}$ & $29.55 \pm 2.39^{2}$ \\
\hline & $\mathrm{C}$ & $4.94 \pm 0.15^{\mathrm{a}}$ & $05.3 \pm 0.70^{c}$ & $0.4 \pm 0.01^{b}$ & $2.37 \pm 1.04^{\mathrm{a}}$ & $39.08 \pm 6.26^{\mathrm{b}}$ & $5.27 \pm 0.16^{\mathrm{a}}$ & $1.50 \pm 0.26^{\mathrm{b}}$ & $28.55 \pm 5.65^{2}$ \\
\hline & Probability & 0.148 & 0.0002 & 0.0002 & 0.602 & 0.014 & 0.101 & 0.018 & 0.166 \\
\hline & Significance & NS & THS & THS & NS & $\mathrm{S}$ & NS & $\mathrm{S}$ & NS \\
\hline \multirow{6}{*}{$\begin{array}{l}20-40 \\
\mathrm{~cm}\end{array}$} & ZF-SR & $4.90 \pm 0.14^{\mathrm{a}}$ & $7.6 \pm 1.70^{\mathrm{a}}$ & $0.6 \pm 0.10^{\mathrm{a}}$ & $1.21 \pm 0.26^{\mathrm{a}}$ & $40.08 \pm 9.56^{\mathrm{a}}$ & $6.89 \pm 0.68^{\mathrm{a}}$ & $0.93 \pm 0.17^{\mathrm{a}}$ & $13.73 \pm 3.52^{2}$ \\
\hline & ZF & $4.75 \pm 0.08^{\mathrm{a}}$ & $6.9 \pm 1.20^{\mathrm{a}}$ & $0.5 \pm 0.08^{\mathrm{a}}$ & $1.07 \pm 0.45^{\mathrm{a}}$ & $22.38 \pm 2.09^{b}$ & $7.84 \pm 1.08^{\mathrm{a}}$ & $0.83 \pm 0.05^{\mathrm{a}}$ & $10.71 \pm 1.00^{2}$ \\
\hline & SR & $4.91 \pm 0.26^{\mathrm{a}}$ & $6.0 \pm 0.71^{\mathrm{a}}$ & $0.5 \pm 0.01^{\mathrm{a}}$ & $0.90 \pm 0.12^{\mathrm{a}}$ & $26.05 \pm 2.83^{\mathrm{a}}$ & $5.88 \pm 1.64^{\mathrm{ab}}$ & $0.81 \pm 0.05^{\mathrm{a}}$ & $14.18 \pm 3.12^{2}$ \\
\hline & $\mathrm{C}$ & $4.86 \pm 0.14^{\mathrm{a}}$ & $5.8 \pm 0.18^{\mathrm{a}}$ & $0.5 \pm 0.03^{\mathrm{a}}$ & $1.32 \pm 0.49^{\mathrm{a}}$ & $30.39 \pm 8.40^{\mathrm{a}}$ & $5.43 \pm 0.33^{b}$ & $0.84 \pm 0.35^{\mathrm{a}}$ & $15.48 \pm 6.66^{2}$ \\
\hline & Probability & 0.520 & 0.448 & 0.369 & 0.554 & 0.049 & 0.039 & 0.869 & 0.538 \\
\hline & Significance & NS & NS & NS & NS & $\mathrm{S}$ & $\mathrm{S}$ & NS & NS \\
\hline
\end{tabular}

$\mathrm{ZF}$ :Zaï forest; SR : Stone rows, ZF-SR : Zaïforest+stone rows; C= control

$\mathrm{SOC}=$ Soil organic carbon, $\mathrm{N}=$ Total nitrogen, Exc- $\mathrm{P}=$ Exchangeable phosphorus, Avail-K = Available potassium, $\mathrm{CEC}=$ Cation exchange capacity, $\mathrm{SBE}=$ sum of exchangeable bases, V=Rate of saturation; NS = No significant, $\mathrm{S}$ : Significant; HS : High significant ; VHS : Very high Significant

The treatments with the same letter in the same column are not statistically different at $\mathrm{p}=0.05$ with StudentNewman-Keuls test for this parameter.

\subsection{Carbonsequestration}

\subsubsection{Soilcoarse fraction}

Table 4 presents the results of the analysis of the coarse fraction of the soil. In the $0-20 \mathrm{~cm}$ depth, the coarse fraction varies significantly between different treatments $(\mathrm{p}<0.05)$. The highest value $(56.37 \%)$ is observed in SR and the lowest value $(25.73 \%)$ in $\mathrm{ZF}$. On the 20-40 cm depth, the coarse fraction effect is highly significant $(\mathrm{p}<0.01)$ between the treatments. The highest value is recorded in $\mathrm{C}(57.41 \%)$ and the lowest value in $\mathrm{ZF}(28.16 \%)$.

\section{Table 4: Soil coarse fraction (Frag) on two depths}

\begin{tabular}{lll}
\hline Treatments & $\begin{array}{l}\text { Frag }(\%) \\
0-20 \mathrm{~cm}\end{array}$ & $\begin{array}{l}\text { Frag (\%) } \\
20-40 \mathrm{~cm}\end{array}$ \\
\hline ZF-SR & $45.12 \pm 7.54^{\mathrm{a}}$ & $48.52 \pm 1.87^{\mathrm{a}}$ \\
ZF & $25.73 \pm 7.55^{\mathrm{b}}$ & $28.16 \pm 4.69^{\mathrm{b}}$ \\
$\mathrm{SR}$ & $56.37 \pm 18.37^{\mathrm{a}}$ & $52.50 \pm 3.22^{\mathrm{a}}$ \\
$\mathrm{C}$ & $46.76 \pm 10.71^{\mathrm{a}}$ & $57.41 \pm 7.78^{\mathrm{a}}$ \\
Probability & 0.04 & 0.001 \\
Significance & $\mathrm{S}$ & HS \\
\hline
\end{tabular}

$\mathrm{ZF}$ :Zaï forest; SR : Stone rows, ZF-SR : Zaïforest+stone rows; $\mathrm{C}=$ control

The treatments with the same letter in the same column are not statistically different at $\mathrm{p}=0.05$ with Student-Newman-Keuls test for this parameter.

S : Significant ; HS : High Significant.

\section{II.3.2 Soil carbon stock}

The organic carbon stock values of the different treatments at depths $0-20 \mathrm{~cm}$ and $20-40 \mathrm{~cm}$ are given in Table 5.

On the first depth, the organic carbon stock was significantly and positively influenced by the different treatments $(p<0.01)$. Compared to C, treatments $\mathrm{ZF}, \mathrm{ZF}-\mathrm{SR}$ and SR resulted in respective organic carbon stock increases of $166 \%, 77 \%$ and $21 \%$. Over the $20-40 \mathrm{~cm}$ depth, the ZF and ZF-SR treatments significantly improved $(\mathrm{p}<0.05)$ the organic carbon stock. The increases over $\mathrm{C}$ were $86 \%$ 
and $47 \%$ for ZF and ZF-SR. Organic carbon stocks of $\mathrm{SR}$ and $\mathrm{C}$ remained approximately the same on this horizon. Comparing the carbon stock on both depths, we noted that it fellsharply from the $0-20 \mathrm{~cm}$ depth to the $20-40 \mathrm{~cm}$ depth. This decrease is $69 \%, 64 \%, 73 \%$ and $56 \%$ respectively for ZF, ZF-SR, SR and C.

Table5: Soil organic carbon stock on $0-20$ and 20-40 $\mathrm{cm}$ depht

\begin{tabular}{lll}
\hline Treatments & $\begin{array}{l}\text { SOC }(\mathrm{t} \mathrm{C} / \mathrm{ha}) \\
0-20 \mathrm{~cm}\end{array}$ & $\begin{array}{l}\text { SOC (t C/ha) } \\
20-40 \mathrm{~cm}\end{array}$ \\
\hline ZF-SR & $11.81 \pm 1.16^{\mathrm{b}}$ & $4.30 \pm 1.14^{\mathrm{a}}$ \\
ZF & $17.75 \pm 2.07^{\mathrm{a}}$ & $5.43 \pm 1.99^{\mathrm{a}}$ \\
$\mathrm{SR}$ & $8.03 \pm 3.29^{\mathrm{c}}$ & $2.14 \pm 0.32^{\mathrm{b}}$ \\
$\mathrm{C}$ & $6.66 \pm 0.49^{\mathrm{c}}$ & $2.92 \pm 2.28^{\mathrm{b}}$ \\
Probability & 0.001 & 0.043 \\
Significance $\quad \mathrm{HS}$ & $\mathrm{S}$ \\
\hline ZF :Zaï forest; SR : Stone rows, ZF-SR : Zaï \\
forest+stone rows; C= control \\
HS : High significant ; S : Significant. \\
The treatments with the same letter in the same \\
column are not statistically different at p=0.05 with \\
Student-Newman-Keuls test for this parameter.
\end{tabular}

\section{Discussion \\ III.1. Physical properties}

In the 0-20 horizon, managed treatments (ZF-SR, ZF and SR) improved the texture by increasing the proportion of the silt and clay fraction at the expense of sand. Indeed, the sandy fraction is a factor that promotes the loss of water and nutrients by leaching. Our results were in keeping with those of Yaméogo (2016)who found that ZF-SR, ZF and SR treatments significantly reduced coarse sand content and significantly improved clay and silt contents compared to the control. According to him, those treatments reduced the speed of runoff water and water erosion, which allowed the retention and accumulation of soil fine particles.ZF-SR is the treatment that ensured the best reduction of runoff water velocity because it combined the impact of $\mathrm{ZF}$ with that of the SR. According to Baye and Terefe (2009), Kassa et al. (2017), soil and water conservation techniques play an important role in controlling runoff and sediment transport.

In depth $20-40 \mathrm{~cm}$, variations of the content of different physical parameters are not significant. This could mean that the improvement of the soil texture by the treatments is progressive from superficial horizons towards the deep horizons of soil.

\section{III.2 Chemical properties}

The ZF, ZF-SR and SR treatments had organic carbon and total nitrogen contents higher than $\mathrm{C}$ in 0 $20 \mathrm{~cm}$ depth. This could reflect an improvement in the organic status of this horizon, due to the nature of the devices in place, which allowed better retention of organic particles. The higher content of the $\mathrm{ZF}$ treatment in organic carbon and total nitrogen compared to SR, could be explained not only by the contribution of compost in the ZF holes, but also by the fact that they constituted "dumps" organic debris from runoff and wind action. Our results are in agreement with those of Zougmoré et al. (2000) according to which the ZF would increase soil organic matter more than stone rows. In addition, Barton et al. (2016) attests that soil management with organic matter input increases productivity and soil nitrogen content.

With regard to the exchangeable phosphorus, the ZFSR, ZF and SR treatments had contents higher than C. The low value of $P$ in $C$ could be attributed to the fact that it records the lowest values of the other chemical parameters and in clay. In fact, the natural affinity of soil to immobilize phosphorus would vary according to its chemical properties such as aluminum, OM, calcium and pH (Sims et al., 2002, Daly et al., 2015; Thomas et al., 2016). Other researchers (Svanback et al., 2014) link soil phosphorus loss to clay content and soil porosity. Treatments ZF-SR, ZF and SR have improved the available potassium content compared to $\mathrm{C}$. But unlike the available phosphorus, ZF-SR recorded the highest content of the available potassium. This could reflect the fact that the available potassium content in the soil does not depend only on soil organic matter, but also on soil type (Ouédraogo, 2013). For chemical parameters such as CEC and SBE, the ZF$\mathrm{SR}, \mathrm{ZF}$ and SR treatments recorded higher levels than C. The ZFtreatment showed the highest CEC and SBE valuesas well as the saturation ratio because its organic matter level was higher. Thus, Ouédraogo (2004), Kihara et al. (2016) indicate that organic matter increases the CEC and thus the quantity and availability of mineral elements in the soil.

In the 20-40 cm depth, the ZF, ZF-SR and SR treatments had organic carbon contents higher than $\mathrm{C}$. However, those values remained lower than in the first horizon. It was the same for CEC and SBE. This also showed that the impact of the techniques is more perceptible in the superficial horizons than in the deep horizons for the chemical elements.

\section{III.3. Soil carbon stock}

The treatments showed a higher organic carbon stock than the control plot in depths $0-20 \mathrm{~cm}$ and $20-40 \mathrm{~cm}$. This proved that treatments have helped to better sequester carbon in the soil. The treatments would thus contribute to the improvement of the physical and chemical conditions for a better carbon sequestration on the lands where they are applied.

In general, there is a decrease in the carbon stock according to the soil profile for all treatments. This 
decrease is lesser at the control level (56\%) compared with ZF-SR (64\%), ZF (69\%) and SR (73\%) treatments. This could reflect an improvement in the organic carbon stock more rapidly at the superficial horizons. This finding of the concentration of carbon stock in the first centimeters of soil has also been reported by several authors (Martin et al., 2011; Koala et al., 2015; Yang et al., 2016; Brahma et al., 2018; Gao et al., 2017). In addition, the ZF-SR and $\mathrm{ZF}$ treatments induced a large development of herbaceous and woody plants with a deposit of a large amount of litter. These plants also allow, through the residues of their root system, a significant sequestration of carbon in the superficial horizons of the soil (Lockwell et al., 2012; Zatta et al., 2014; Richter et al., 2015; Clifton-Brown et al., 2007). Indeed, according to Chenu et al. (2014) the duration of residence of $\mathrm{C}$ in soil depends on the composition of organic matter and local conditions (temperature, humidity, aeration, etc.). In addition, this time is increased by the association of organic matter with soil mineral particles, in particular clay, which providea physicochemical protection of MO with respect to the action of decomposing microorganisms (Deenik, 2006; Lal, 2004b, Alberti et al., 2015). According to Merante et al. (2017) and Lal (2004a) management practices can significantly influence the ability of the soil to sequester SOC through the improvement of micro-aggregates stability, humification, translocation of organic carbon from the soil to deep horizons avoiding erosion and carbonate formation. In addition, Barton et al. (2016) concluded that incorporation of OM into the soil reduces greenhouse gases.

\section{Conclusion}

The purpose of this study was to evaluate the impact of three water and soil conservation techniques on soil carbon sequestration and on the evolution of some physicochemical parameters of the soil in a degraded forest ecosystem. The results showed that the three techniques (ZF, SR, ZF-SR) significantly improved the mineral soil texture by increasing the rate of the clay and silt fraction to the detriment of the sandy one in the $0-20 \mathrm{~cm}$ depth. The same observation was noticed with organic carbon, $\mathrm{N}$, avail-K and SBE. The organic carbon stock was significantly and positively influenced by the different treatments. ZF, ZF-SR and SR treatments resulted in respective organic carbon stock increase of $166 \%, 77 \%$ and $21 \%$ in the $0-20 \mathrm{~cm}$ depth compared with $\mathrm{C}$. This study proved the need to implement those techniques in forest ecosystems under the influence of human actions to increase their resilience and fight against climate change.

\section{Competing interests}

The authors declare that they have no competing interests

\section{Acknowledgements}

Funded thanks to the International Foundation for Science (IFS), which fully funded this work through the fellowship agreement D/4981-2.

\section{References}

1. Alberti, G., Vicca, S., Inglima, I., Belelli-Marchesini, L., Genesio, L., Miglietta, F., Marjanovic, H., Martinez, C., Matteucci, G., D’Andrea, E., Peressotti, A., Petrella, F., Rodeghiero, M. and Cotruf, M. F.(2015). Soil C:N stoichiometry controls carbon sink partitioning between above-ground tree biomass and soil organic matter in high fertility forests. iForest - Biogeosciences and Forestry,8: $195-20$

2. Arrouays, D., Feller, C., Jolivet, C., Saby, N., Andreux, F., Bernoux, M. ad Cerri C.(2003). Estimation de stocks de carbone organique des sols à différentes échelles d'espace et de temps. Étude et Gestion des Sols, 10 (4) : 347-355

3. Aynekulu, E., Vagen, T-G., Shepherd, K. and Winowiecki, L. (2011).A protocol for measurement and monitoring soil carbon stocks in agricultural landscapes. Version 1.1. World Agroforestry Centre, Nairobi. http://www.worldagroforestry.org/downloads/Publications/P DFS/TM11192.pdf>.Accessed on6 May 2016.

4. Barton, L., Hoyle, F.C., Stefanova, K.T. and Murphy, D. V.(2016). Incorporating organic matter alters soil greenhouse gas emissions and increases grain yield in a semi-arid climate. Agriculture, Ecosystems and Environment, 231: 320330 .

5. Baye, M. and Terefe, B.(2009). The experience of coffee plantation development enterprise in Ethiopia.Ethiopia workshop paper. AddisAbaba.

6. Bopp, L., Bowler, C., Guidi, L., Karsenti, E. and Vargas, C.(2015). L'océan, pompe à carbone: un rôle majeur pour l'océan dans l'évolution du $\mathrm{CO} 2$ atmosphérique. $<$ http://www.ocean-climate.org/wpcontent/uploads/2015/03/FichesScientifiques-ocean-pompecarbone.pdf $>$. Accessed on 29 June 2016.

7. Brahma, B., Pathak, K., Lal, R., Kurmi, B., Das, M., Nath, P.C., Nath, A.J. and Ashesh Kumar Das, A.K. (2018). Ecosystem carbon sequestration through restoration of degraded lands in Northeast India.Land Degrad Develop, 29:15-25.

8. Bremner, J.M.(1965). Total nitrogen.Part 2:Chemical and Microbiological Properties, in: Black CA. (Eds.), Methods of Soil Analysis. American Society of Agronomy, Inc., Madison WI, pp. 1149-1178.

9. BUNASOLS. (1987). Méthodes d'analyse physique, chimique des sols, eaux, plantes. Document technique $\mathrm{n}^{\circ} 3$. Ouagadougou : Bunasols.

10. Chenu, C., Klumpp, K., Bispo, A., Angers, D., Colnenne, C. and Metay A. (2014). Stocker du carbone dans les sols agricoles : évaluation de leviers d'action pour la France. Innovations Agronomiques, 37 : 23-37.

11. Clifton-Brown, J.C., Breuer, J. and Jones, M.B. (2007).Carbon mitigation by the energy crop, Miscanthus. Glob. Change Biol., 13: 2296-2307.

12. Daly, K., Styles, D., Lalor, S. and Wall, D. P.(2015). Phosphorus sorption supply potential and availability in soil with contrasting parent material and soil chemical properties. Eur. J. Soil Sci., 66: 792-801.

13. Deenik, J. (2006). Nitrogen Mineralization Potential in Important Agricultural Soils of Hawai.Soil and Crop Management. SCM-15

14. Fontaine, S., Bardoux, G., Abbadie, L. and Mariotti, A.(2004).Carbon input to soil may decrease soil carbon 
content. EcologyLetters 7: 314-320. -doi: 10.1111/j.14610248.2004.00579.x

15. Fontès, J. and Guinko, S.(1995). Carte de la végétation et de l'occupation du sol du Burkina Faso/Notice explicative. Laboratoire d'Ecologie Terrestre, Institut de la Carte Internationale de la Végétation. Université de Toulouse III (France)/Institut du Développement Rural, Faculté des Sciences et Techniques, Université de Ouagadougou (Burkina Faso).

16. Gao, X., Meng, T. and Zhao, X.(2017). Variations of Soil Organic Carbon Following Land Use Change on Deep-Loess Hillsopes in China.Land Degrad. Develop. 28: 1902-1912. DOI: 10.1002/ldr.2693

17. Gomgnimbou, P.K.A., Savadogo, W.P., Nianogo, J.A. and Millogo-Rasolodimby, J. (2010). Pratiques agricoles et perceptions paysannes des impacts environnementaux de a cotonculture dans la province de la KOMPIENGA (Burkina Faso). Sciences \& Nature, 7(2) : 165-175.

18. Hassan, R.M. (2010). Implications of Climate Change forAgricultural Sector Performance in Africa: Policy Challenges and Research Agenda. Journal of african économies, 19(2) : 77-105.

19. IAD (2013). Réinventons l'énergie de la terre. Augmenter la séquestration du carbone dans le sol http://agridurable.fr/fr/augmenter-le-carbone-dans-les-sols $>$. Accessed on12 April 2016.

20. INRA.(2015). 4 pour 1000, la séquestration du carbone dans les sols. Des sols pour la sécurité alimentaire et le climat. https://inra-dam-front-resources-

cdn.brainsonic.com/ressources/afile/312559-2a97f-resource4-pour-1000-4-pages-version-francaise.html. Accessed on 7 July 2016.

21. Jandl, R., Lindner, M., Vesterdal, L., Bauwens, B., Baritz, R., Hagedorn, F., Johnson, D.W., Minkkinen, K. and Byrne, K.A. (2007). How strongly can forest management influence soil carbon sequestration? Geoderma, $137: 253-268$.

22. Jobbágy, E.G. and Jackson, R.B. (2000). The vertical distribution of soil organic carbon and its relation to climate and vegetation. Ecological Applications, 10: 423-436.

23. Kassa, H., Dondeyne, S., Poesen, J., Frankl, A. and Nyssen, J.(2017). Transition from Forest-based to Cereal-based Agricultural Systems: A Review of the Drivers of Land use Change and Degradation in Southwest Ethiopia. Land Degrad. Develop. 28: 431-449. DOI: 10.1002/ldr.2575

24. Kihara, J., Nziguheba, G., Zingore, S., Coulibaly, A., Esilaba, A., Kabambe, V., Njoroge, S., Palm, C. and Huising, J.(2016). Understanding variability in crop response to fertilizer and amendments in sub-Saharan Africa.Agriculture, Ecosystems and Environment, 229: 1-12.

25. Koala, J., Sawadogo, L., Savadogo, P., Zida, D., Aynekulu, E., Saïd, M. and Nacro, H.B.(2015). Cumulative effects of 20 years of livestock grazing, prescribed early fire and selective tree cutting on belowground biomass in sudanian savanna woodland. International Journal of Current Research, 7 : 13603-13613

26. Koala, J.(2016). Influences des perturbations anthropiques sur le stock de carbone dans les écosystèmes de savane en zone soudanienne du Burkina Faso. Thesis, Institut du Développement Rural, Université Polytechnique de Bobo.

27. Lal, R. (2004a). Soil carbon sequestration to mitigate climate change. Geoderma 123:1-22.

28. Lal, R. (2004b). Soil carbon sequestration impacts on global climate change and food security. SCIENCE, 304: 1623 1627

29. Li, X.J., Li, X.R., Wang, X.P. and Yang, H.T. (2016). Changes in soil organic carbon fractions after afforestation with xerophytic shrubs in the Tengger Desert, northern China. European Journal of Soil Science, 67: 184-195

30. Loveland, P.J. and Whalley, WR. (1991). Particle size Analysis, in: Smith KA, and Mullis CE. (eds), Soil Analysis: Physical Methods. Marcel Dekker Inc., New York. pp. 271328.
31. Lockwell, J., Guidi, W. and Labrecque, M. (2012). Soil carbon sequestration potential of willows in short-rotation coppice established on abandoned farm lands. Plant Soil, 360: 299-318

32. Martin, M.P., Wattenbach, M., Smith, P., Meersmans, J., Jolivet, C., Boulonne, L. and Arrouays, D. (2011). Spatial distribution of soil organic carbon stocks in France. Biogeosciences, 8: 1053-1065.

33. Merantea, P., Dibari, C., Roberto, Ferrise, R., Sánchez, B. Iglesias, A., Lesschen, J.P., Kuikman, P., Yeluripati, J., Smith, P. and Bindi M. (2017). Adopting soil organic carbon management practices in soils of varying quality: Implications and perspectives in Europe. Soil \& Tillage Research, 165:95-106.

34. Ouédraogo, E.(2004). Soil quality improvement for crop production in semi-arid West Africa.Thesis, Wegeningen University and Research Center, Netherland, $191 \mathrm{p}$.

35. Ouédraogo, B.(2013). Relation entre potassium échangeable, matière organique et teneur en argile des sols dans les rotations coton-céréales sous culture. Mémoire de fin de cycle, Université Polytechnique de Bobo-Dioulaso.

36. Ouoba, P.A., Da, E.C.D. and Paré, S. (2013). Perception paysanne des changements climatiques et environnementaux et stratégies d'adaptation dans les régions sèches africaines. LaSyRe Working Paper No. 9-2013

37. Quiroga, A., Funaro, D., Noellemeyer, E. and Peinemann, N. (2006)."Barley yield response to soil organic matter and texture in the Pampas of Argentina". Soil \& Tillage Research , 90: 63-68.

38. Richter, G.M., Agostini, F., Redmile-Gordon, M., White, R. and Goulding, K.W.T.(2015). Sequestration of C in soils under Miscanthuscan be marginal and is affected by genotype-specific root distribution. Agriculture, Ecosystems and Environment, 200 : 169-177.

39. Robert, M. and Saugier, B. C. (2003).Contribution des écosystèmes continentaux à la séquestration du carbone. Geoscience, 335 : 577-595. doi:10.1016/S1631 0713(03)00094-4

40. Sahilemedhin, S. and Taye, B.(2000)."Procedures for Soil and Plant Analysis", National Soil Research Center, Ethiopian Agricultural Research Organization, Technical paper No. 74. Addis Ababa, Ethiopia.

41. Sims, J.T., Maguire, R.O., Leytem, A.B., Gartley, K.L. and Pautler, M.C. (2002). Evaluation of Mehlich 3 as an agrienvironmental soil phosphorus test for the Mid-Atlantic United States of America. Soil Sci. Soc. Am. J., 66: 20162032.

42. Svanbäck, A., Ulén, B. and Etana, A. (2014). Mitigation of phosphorus leaching losses via subsurface drains from a cracking marine clay soil.Agriculture, Ecosystems and Environment 184 124-134. doi.org/10.1016/j.agee.2013.11.017.

43. Six, J., Callewaert, P., Lenders, S., Gryze, S.D., Morris, S.J., Gregorich, E.G., Paul, E.A. and Paustian, K.(2002). Measuring and understanding carbon storage in afforested soils by physical fractionation. Soil Science Society America Journal, 66: 1981-1987.

44. Thomas, I.A., Mellandera, P.-E., Murphy, P.N. C., Fenton, O., Shine, O., Djodjic, F., Dunlop, P. and Jordan, P. (2016). A sub-field scale critical source area index for legacy phosphorus management using high resolution data. Agriculture, Ecosystems and Environment, 233: 238-252.

45. Ouattara, I., Chouinard, O., Tranchant, C.C. and Vanderlinden (2008). Changements climatiques, migrations et défis de la gestion de l'environnement : le cas d'un village au cour de la tourmente au Burkina Faso. VertigO-la revue électronique en sciences de l'environnement, 8(3).

46. Van Reeuwijk, L.P. (2002). Procedures for soil analysis.Sixth edition Technical Report 9.ISRIC-Word Soil Information, Wageningen, Netherlands.

47. Walkley, A. and Black, I.A.(1934). An examination of Degtjareff method for determining soil organic matter and a 

in West Africa (Burkina Faso)

proposed modification of the chronic acid titration method. Soil Science, 37 : 29-38.

48. Yaméogo, J.T., Somé, A.N., Lykke, A.M., Hien, M. and Nacro, H.B.(2013). Restauration des potentialités de sols dégradés à l'aide du zaï et des cordons pierreux à l'ouest du Burkina Faso. Tropicultura, 31(4) :224-230

49. Yaméogo, J. T.(2016). Réhabilitation d'écosystème forestier dégradé en zone soudanienne: Impacts des techniques de conservation des eaux et des sols/défense et restauration des sols à l'ouest du Burkina Faso. Presses académiques francophones, Sarrebruck, Allemagne, $234 \mathrm{p}$.

50. Yang, R-M., Zhang, G-L., Yang, F., Zhi, J-J., Yang, F., Liu, F., Zhao, Y-G. and Li,D-C. (2016). Precise estimation of soil organic carbon stocks in the northeast Tibetan Plateau. Scientific Reports, 6:21842 |DOI: 10.1038/srep21842

51. Zatta, A., Clifton-Brown, J., Robson, P., Hastings, A. and Monti, A. (2014). Land use change from $\mathrm{C}_{3}$ grassland to $\mathrm{C}_{4}$ Miscanthus: effects on soil carbon content and estimated mitigation benefit after six years. GCB Bioenergy. 6: 360370 .

52. Zougmoré, R., Guillobez, S., Kambou, N.F. and Son, G. (2000). Runoff and sorghum performance as affected by the spacing of stone lines in the semiarid Sahelian zone. Soil and Tillage Research, $56 \quad$ : 175-183. 